\title{
RWDD3 wt Allele
}

National Cancer Institute

\section{Source}

National Cancer Institute. RWDD3 wt Allele. NCI Thesaurus. Code C105965.

Human RWDD3 wild-type allele is located in the vicinity of 1 p21.3 and is approximately 13

$\mathrm{kb}$ in length. This allele, which encodes RWD domain-containing protein 3 , is involved in the regulation of protein sumoylation. 